\title{
Evaluasi Program Pembinaan Prestasi Cabang Olahraga Bulutangkis di Persatuan Bulutangkis (PB) Anugerah Denpasar dengan Metode Contex, Input, Procces, Product (CIPP)
}

\author{
I Putu Widi Diatmika ${ }^{1 *}$, I Putu Widi Diatmika ${ }^{2}$, Gede Doddy Tisna ${ }^{3}$ \\ 123 Jurusan Ilmu Olahraga dan KesehataUniversitas Pendidikan Ganesha \\ *Corresponding author: putu.widdiatmika@undiksha.ac.id
}

\begin{abstract}
Abstrak
Dalam upaya meningkatkan prestasi olahraga bulutangkis, maka perlu dilakukan evaluasi program pembinaan olahraga Bulutangkis di PB. Anugerah secara mendalam, sebagai dasar pemetaan pembinaan olahraga berkelanjutan. Penelitian ini bertujuan untuk mengetahui pelaksanaan program pembinaan prestasi cabang olahraga bulutangkis di PB. Anugerah Denpasar dengan pendekatan evaluasi CIPP Model. Subyek penelitian meliputi pengurus, atlet, dan pelatih. Instrumen yang digunakan angket dan pedoman wawancara. Didapat hasil pada dimensi contex bahwa diperlukan adanya peningkatan dan pembenahan misalkan dengan menerapkan fungsi manajemen serta keaktifan semua anggota pengurus sangat diharapkan dalam rangka memaksimalkan kegiatan agar pembinaan prestasi berjalan maksimal. Pada input masuk dalam kategori cukup baik dikarenakan sarana dan prasarana yang terdapat di klub bulutangkis PB. Anugerah Denpasar sudah layak dan memadai. Dalam hal gedung bulutangkis sudah milik pribadi empat lapangan karpet, net beserta kursi wasit, shuttlecock, cone dan agility leader. Pada dimensi procces menyatakan bahwa pelaksanaan program pembinaan berupa program pembinaan usia dini, pemanduan bakat, dan program pembinaan prestasi berjalan cukup baik yaitu pelaksanaan kejuaraan-kejuaraan yang rutin dilakukan setiap tahunnya. Monitoring dan evaluasi yang dilakukan rutin oleh pelatih dan pengurus. Pada dimensi product, hasil yang didapat dari program pembinaan yang telah dijalankan masih dalam kategori baik berupa menjadi runner up pada Walikota Cup 2019. Hal yang perlu dikembangkan berupa pembinaan yang terarah terprogram dan lebih maksimal agar atlet PB. Anugerah Denpasar mampu berprestasi di tingkat nasional.
\end{abstract}

Kata Kunci : Evaluasi, CIPP, pembinaan, bulutangkis

\section{Abstract}

It is necessary to evaluate the badminton sports coaching program in PB to improve badminton performance. Anugerah indepth, as the basis for mapping sustainable sports development. This study aims to determine the implementation of the badminton achievement development program in PB. Anugerah Denpasar with the CIPP Model evaluation approach. Research subjects include administrators, athletes, and coaches. The instruments used were questionnaires and interview guidelines. The results obtained on the context dimension that there is a need for improvement and improvement, for example, by implementing the management function and the activeness of all board members, is highly expected to maximize development runs optimally. The input is in the fairly good category due to the facilities and infrastructure found in the PB badminton club. The Denpasar Award is worthy and adequate. If the badminton building is privately owned, four carpet courts, nets and referee chairs, shuttlecocks, cones and agility leaders. In the process dimension, it is stated that the implementation of the coaching program in the form of an early childhood development program, talent scouting, and achievement coaching program is running quite well, namely the implementation of championships which are routinely carried out every year. Regular monitoring and evaluation by trainers and administrators. In the product dimension, the results obtained from the coaching program that has been carried out are still in the good category in being a runner up at the 2019 Mayor Cup. What needs to be developed is targeted, programmed, and more optimal coaching so that PB Anugerah Denpasar athletes can excel at the national level.

Keywords: evaluation, CIPP, coaching, badminton

History:
Received: 30 April 2020
Revised: 25 Mei 2020
Accepted: 03 Juni 2020
Published: 28 Juni 2020




\section{Pendahuluan}

Masalah pendidikan di Indonesia, salah satunya masih berkutat pada persoalan mutu. Sampai saat ini, mutu pendidikan Indonesia masih ketinggalan jauh dibandingkan negara-negara lain di dunia, termasuk di Asia (Nilan, 2009). Rendah- nya mutu pendidikan berimplikasi pada rendahnya pula Sumber Daya Manusia (SDM). Data UNDP tahun 2009 (Kompas, 2011a) menunjuk- kan bahwa HDI Indonesia masih berada di posisi 111 dari 182 negara, jauh berada di bawah Singapura yang berada diposisi 23, Brunei 30, Malaysia 66, dan Thailand 87. Indeks pemba-ngunan pendidikan untuk semua (education for all) menurut UNESCO dalam EFA Global Monitoring Report 2011, melaporkan bahwa Indonesia menepati urutan 67 dari 127 negara (Kompas, 2011b). Secara khusus, mutu pendidi- kan IPA juga rendah. Berdasarkan survei yang dilakukan oleh Konsorsium Internasional (2010), melaporkan bahwa dalam bidang IPA, Indonesia masuk peringkat 32 dari 36 negara (Kusmariyatni, 2012)

Teori pendidikan merupakan landasan dan pijakan awal dalam pengembangan praktik pendidikan, misalnya pengembangan kurikulum, manajemen sekolah dan proses belajarmengajar. Kurikulum dan pembelajaran memiliki keterkaitan dengan teori pendidikan atau dalam penyusunan suatu kurikulum dan rencana pembelajaran ini mengacu pada teori pendidikan. Berbagai teori yang dikembangkan saat ini telah mewarnai proses dan praktik pendidikan. Sumbangsih para tokoh dalam menciptakan teori telah memberikan perkembangan dan kemajuan dalam proses pendidikan. Lahirnya teori dalam bidang pendidikan memberikan warna baru terhadap sistem pendidikan, proses belajar mengajar, manajemen sekolah dan metode pembelajaran.

Adanya pergeseran metode dan pola didik pengajar terhadap peserta didik merupakan proses dari pelaksanaan teori dalam bidang pendidikan. Sebagai contoh berkembangnya pola pendidikan active learning dimana proses pembelajaran tidak hanya terpusat pada pengajar akan tetapi peserta didik mempunyai peranan sangat menentukan hasil belajar. Hal ini dipelopori oleh teori yang berkembang yaitu teori behaviorisme dimana setiap manusia mempunyai kemampuan untuk berfikir dan melakukan setiap aktifitas dalam proses belajar. Sehingga dengan teori ini setiap peserta didik diberikan ruang kebebasan untuk melakukan kegiatan yang disesuaikan dengan kemampuan peserta didik, tugas pengajar bersifat pengarah dan fasilitator, hal ini memungkinkan terbentuknya rasa percaya diri serta kemampuan peserta didik untuk menciptakan hal-hal yang inovatif dan kreatif (Sholichah, 2018)

Pendidikan jasmani pada dasarnya merupakan bagian integral dari sistem pendidikan secara keseluruhan, bertujuan untuk mengembangkan aspek kesehatan, kebugaran jasmani, ketrampilan berfikir kritis, stabilitas emosional, ketrampilansosial, penalaran dan tindakan moral melalui aktivitas jasmani dan olahraga. Adang Suherman dan Agus Mahendra (2002) mengemukakan bahwa pendidikan jasmani pada dasarnya merupakan pendidikan melalui aktivitas jasmani untuk mencapai perkembangan individu secara menyeluruh. Pendidikan jasmani adalah suatu proses melalui aktivitas jasmani yang desain untuk meningkatkan kebugaran jasmani, mengembangkan ketrampilan motorik, pengetahuan dan perilaku hidup sehat dan aktif, sikap sportif, dan kecerdasan emosi. Lingkungan belajar diatur secara seksama untuk meningkatkan pertumbuhan dan perkembangan seluruh ranah, yaitu jasmani, psikomotor, kognitif dan afektif, karenanya pendidikan jasmani ini harus menyebabkan perbaikan dalam pikiran (psikis) dan tubuh (fisik) yang mempengaruhi seluruh aspek kehidupan harian seseorang. Pendekatan holistik tubuh - jiwa ini termasuk pula penekanan pada ketiga dominan kependidikan: psikomotor, kognitif, afektif. Pendidikan jasmani diharapkan mampu menciptakan tubuh yang baik bagi pikiran atau jiwa.Menurut Harsuki (2003), pendidikan jasmani merupakan bagian integrasi pendidikan keseluruhan 
yang bertujuan meningkatkan individu secara organik, muskuler, intelektual dan emosional melalui aktivitas jasmani (Wicaksono, 2019)

Pendidikan jasmani merupakan bagian yang tidak terpisahkan dari pendidikan nasional yang bertujuan untuk pengembangkan kemampuan peserta didik melalui aktivitas jasmani (Utama Bandi, 2011). Sehingga pendidikan jasmani harus diajarkan kepada setiap peserta didik pada semua jenjang pendidikan. Perencanaan pendidikan jasmani dilakukan secara seksama untuk memenuhi perkembangan, pertumbuhan, dan kebutuhan perilaku setiap anak. Maka pendidikan jasmani bukan hanya ditujukan untuk mengembangkan kemampuan psikomotorik, akan tetapi juga mengembangkan kemampuan kognitif dan afektif peserta didik (Paramitha, 2018)

Bulutangkis merupakan salah satu jenis olahraga yang popular dan banyak digemari masyarakat di dunia khusunya di Indonesia. Perkembangan ini disebabkan karena bulutangkis merupakan salah satu cabang olahraga yang dapat dimainkan oleh semua orang mulai dari anak-anak, orang dewasa sampai orang tua. Bulutangkis telah mencapai tahap perkembangan yang sangat pesat dan menarik perhatian banyak orang. Permainan Bulutangkis ini diciptakan oleh petugas Tentara Britania di Pune, India pada abad ke 19 saat mereka menambahkan jaring dan memainkannya secara bersaingan.

Bulutangkis juga merupakan cabang olahraga yang mengharumkan nama bangsa Indonesia di tingkat dunia. Bulutangkis selalu meraih medali dalam ajang multi event seperti SEA Games, ASIAN Games, hingga Olimpiade. Sejak Olimpiade Barcelona 1992, Bulutangkis selalu meraih medali emas. Namun di Olimpiade London 2012 bulutangkis Indonesia gagal mempersembahkan medali emas. Asal mula olahraga ini belum diketahui secara pasti, karena memang cikal bakal olahraga bulutangkis ini dimainkan di beberapa negara. Hingga saat ini hampir pada setiap negara berlomba-lomba untuk mempelajari, mengembangkan dan mengadakan permainan bulutangkis (Juang, 2015)

Bulutangkis olahraga yang sudah merakyat di Indonesia (Arganata, 2016; Maulina, 2018), bahkan diseluruh Dunia dari yang muda sampai kalangan dewasa, baik perempuan ataupun laki-laki. Poole (2011:14) menyatakan bahwa pada prinsipnya, permainan bulutangkis dapat dilakukan baik di dalam ruangan maupun di luar ruangan. Meskipun demikian, semua turnamen resmi sampai saat ini praktis dilakukan di dalam ruangan. Hal ini dikarenakan, di dalam ruangan laju shuttlecock relatif tidak terpengaruh oleh angina

Di dalam permainan bulutangkis terdapat alat bantu yang digunakan untuk memukul (raket) dan benda yang dipukul (shuttlecock). Bulutangkis merupakan olahraga yang menggunakan alat yang dinamakan raket dan shuttlecock, yang dimainkan oleh dua orang atau empat pemain (Rahmani dalam Saefullah, 2017:13). Cara memainkan olahraga ini adalah dengan memukul shuttlecock dengan menggunakan raket dengan target melewati net yang terletak di tengah lapangan. Jatuh shuttlecock harus tepat berada di daerah lawan, begitupun sebaliknya. (Setiawan, 2020)

Di Indonesia Bulutangkis ditampung dalam sebuah wadah Organisasi yaitu PBSI (Persatuan Bulutangkis Seluruh Indonesia). Dengan adanya PBSI maka akan mendorong perkembangan Bulutangkis di Indonesia serta dengan seringnya diadakan banyak kompetisi bagi kelompok umur, pelajar, mahasiswa, ataupun klub-klub umum yang ada. Diharapkan akan menumbuhkan banyak bibit-bibit muda berbakat dalam membela bangsa di kancah regional ataupun internasional. Salah satu wadah pembinaan dan pembibitan atlet-atlet masa depan adalah di klub-klub bulutangkis yang ada di daerah-daerah, setiap klub harus memiliki suatu program dan system pembinaan yang tepat, apabila system pembinaan dilakukan dan berjalan dengan baik maka perkembangan olahraga khususnya bulutangkis juga akan lebih baik. Cabang olahraga bulutangkis ini merupakan salah satu olahraga yang sangat popular di Indonesia setelah sepak bola. Hampir di setiap sudut kota maupun desa olahraga bulutangkisi ini digemari oleh kalangan muda maupun tua serta banyak didirikannya klub-klub 
bulutangkis yang tersebar diseluruh kota di Indonesia. Misalnya klub bulutangkis PB. Anugerah Denpasar yang merupakan salah satu klub bulutangkis yang telah berdiri cukup lama dan memiliki prestasi yang cukup baik. PB. Anugerah Denpasar ini terletak di Kota Denpasar, lebih tepatnya di GOR Bulutangkis Anugerah Denpasar jalan Antasura Gang Dewi Madri Denpasar Utara yang berdiri sejak tahun 2011, mempunyai 50 atlet yang terdiri dari kelompok umur yakni usia dini, anak, pemula dan remaja. Keadaan dan permasalahan yang ada di PB. Anugerah Denpasar mengenai pelaksanaan, pembinaan prestasi yang mencakup aspek program pembinaan, aspek sarana dan prasarana, aspek organisasi, dan aspek prestasi yang merupakan hasil pembinaan klub.

Dalam upaya meningkatkan prestasi olahraga bulutangkis, maka perlu dilakukan evaluasi program pembinaan olahraga Bulutangkis di PB. Anugerah secara mendalam, sebagai dasar pemetaan pembinaan olahraga berkelanjutan. Penelitian dasar difokuskan pada study survey dan pemetaan berdasarkan evaluasi program pembinaan olahraga bulutangkis di PB. Anugerah Denpasar dengan model CIPP yang memfokuskan pada contect (PB. Anugerah sebagai klub olahraga), input (sarana prasarana, system rekruitmen atlet, bonus, pelatih penentuan target, dan manajemen pengurus PB. Anugerah, procces (program pelatihan, try in/ try out, dan kejuaraan), product (prestasi olahraga). Evaluasi program pembinaan olahraga bulutangkis ini penting dilakukan, untuk menganalisis program pembinaan olahraga bulutangkis.

\section{Metode}

Jenis penelitian yang penulis pilih Penelitian yang akan dilakukan merupakan penelitian deskriptif kualitatif dengan metode survey. Artinya metode ini menggunakan teknik pengumpulan data yaitu menggunakan kuisioner atau angket sebagai data kualitatif. Selanjtnya untuk memperkuat hasil data kuisioner atau angket maka dilengkapi dengan observasi dan wawancara kepada responden yang telah memberikan tersebut yang memahami masalah yang akan ditelitit. (Sugiyono, 2015) dalam Nari (2019:4). Model yang digunakan adalah model Contex, Input, Procces, Product (CIPP). Model CIPP digunakan untuk menganalisis dan pemetaan berdasarkan evaluasi program pembinaan olahraga bulutangkis di Klub PB. Anugerah Denpasar mengenai contect (PB. Anugerah sebagai klub olahraga), input (sarana prasarana, system rekruitmen atlet, bonus, pelatih, penentuan target, dan manajemen pengurus PB. Anugerah, procces (program pelatihan, try in/ try out, dan kejuaraan), product (prestasi olahraga).

Sumber data utama dalam penelitian kualitatif ialah kata-kata, tindakan, selebihnya adalah data tambahan seperti dokumen dan lain-lain. (Lexy J. Meleong, 2001:157). Dalam penelitian ini peneliti menggunakan responden, fasilitas, aktivitas klub, dan dokumen.

a. Responden, merupakan orang yang melakukan jawaban saat interview atau wawancara. Dalam hal ini peneliti melakukan interview dengan responden pemilik klub, pengurus, pelatih dan atlet di klub PB. Anugerah Denpasar

b. Fasilitas klub, fasilitas yang dimaksud adalah sarana dan prasarana yang berupa tempat latihan, serta alat-alat yang digunakan untuk kegiatan pembinaan prestasi olahraga bulutangkis.

c. Aktivitas klub, segala tindakan dan tingkah laku seseorang yang berkaitan dengan aspekaspek pembinaan prestasi olahraga yang berlangsung di tempat kegiatan yang berhubungan dengan pembinaan prestasi olahraga bulutangkis

d. Dokumen, Foto atau gambar dan catatan tertulis yang diperoleh dari tempat peneliti yang berkaitan dengan aspek produksi dan dapat dijadikan data yang pasti. 
Pada metode pengumpulan data, Melakukan observasi Contex mengenai organisasi itu sendiri seperti kapan berdirirnya klub, system pendanaan, AD/ART, hubungan antara pengurus, pelatih, atlet, serta orang tua atlet, dan perekrutan pelatih. Melakukan wawancara dengan pengurus dan pelatih klub mengenai Input seperti sarana dan prasarana, system rekruitmen atlet, bonus, pelatih, dan penentuan target. Melakukan wawancara dengan pelatih dan salah satu atlet mengenai Procces itu sendiri seperti program latihan, model latihan, pembinaan, try in \& try out, dan kejuaraan. Lalu pada Product, pengambilan data arsip atau dokumen prestasi olahraga yang telah dicapai oleh atlet.

\section{Hasil dan Pembahasan}

Selain itu banyak prestasi yang diperoleh atlet-atlet klub bulutangkis PB. Anugerah Denpasar yang mewakili sekolah masing-masing pada kejuaraan tingkat pelajar. Klub bulutangkis PB. Anugerah Denpasar sampai sekarang telah melakukan pembinaan bulutangkis dari berbagi kelompok umur. Mulai dari usia dini, anak-anak, pemula, remaja, dan taruna yang sekarang menjadi atlet senior di klub tersebut. Latihan klub dilaksanakan setiap hari senin hingga sabtu.

Dari segi contex, yang dimana didalamnya memuat tentang organisasi PB. Anugerah tersebut, dari hasil penelitian yang dilakukan, menurut pengurus selaku bendahara bahwa organisasi PB. Anugerah sudah berjalan dengan baik sebagaimana mestinya sebuah organisasi seperti masalah pendanaan yang transparan, memiliki SK Kepengurusan dan hubungan antara pengurus, pelatih dan atlet berjalan baik. Pendanaan, merupakan salah satu faktor yang mendukung hasilnya pembinaan karena tanpa adanya dana, maka pembinaan akan sulit berjalan kearah prestasi yang maksimal (Santoso, H.P., Rahayu, T.,\& Rahayu, 2017)

Organisasi yang baik adalah organisasi yang mempunyai suatu badan, wadah, tempat dari perkumpulan orang-orang yang bekerjasama untuk mencapai suatu tujuan tertentu (Amirullah, 2004) Dan memiliki suatu struktur fungsi dan system kerjasama yang dilakukan berdasarkan aturan dan penjabaran fungsi pekerjaan secara formal. Itu semua terdapat pada PB. Anugerah Denpasar seperti mengatasi pendanaan untuk kegiatan pembinaan di klub bulutangkis tersebut berasal dari iuran bulanan anggota dan sponsor. PB. Anugerah belum memiliki AD/ART. Namun SK Kepengurusan sudah ada. Selama ini aturan-aturan penting yang mengikat sebuah kelompok atau organisasi sudah berjalan sebagaimana mestinya misalnya tujuan pembentukan organisasi, logo resmi, struktur kepengurusan, agenda rapat rutin dan sebagainya.

Sarana dan prasarana olahraga adalah suatu kegiatan yang dimanfaatkan dalam melaksanakan pendidikan jasmani yang meliputi lapangan dan bangunan olahraga beserta perlengkapan untuk melaksanakan proses belajar dan mengajar (Soepartono, 2000). Itu tertuang dalam data yang diperoleh hasil wawancara bersama salah satu pengurus yang bernama Bapak Made Wirawan selaku bendahara dan pelatih Risa Rival Gonesi, didapat hasil bahwa sarana dan prasarana yang terdapat di klub bulutangkis PB. Anugerah Denpasar sudah layak dan memadai dalam hal gedung bulutangkis yang sudah milik pribadi dibandingkan dengan klub bulutangkis lainnya yang masih kebanyakan menyewa.

Evaluasi program pada dasarnya untuk mengetahui sampai sejauh mana rencana telah diterapkan dan komponen apa yang perlu diperbaiki (Widoyoko, 2016). Evaluasi Input pada cabang olahraga bulutangkis. Hasil wawancara yang dilakukan bersama pelatih Risa Rival Gonesi dan salah satu atlet yang bernama Hogy Andrean menyatakan bahwa pelaksanaan program pembinaan berupa program pembinaan usia dini, pemanduan bakat, dan program pembinaan prestasi sudah berjalan baik yaitu pelaksanaan kejuaraan-kejuaraan yang rutin dilakukan setiap tahunnya 
Menurut (Farsi \& Sharif ) dalam Nasri (2019:10) evaluasi product merupakan pengumpulan data untuk mengetahui sejauh mana tujuan tersebut tercapai. Evaluasi product berisi tentang prestasi yang telah diraih atlet dari tingkat daerah sampai tingkat internasional. Berdasarkan hasil angket, observasi, dan dokumentasi yang dilakukan menunjukkan bahwa program pembinaan prestasi bulutangkis di PB. Anugerah pada aspek product atau prestasi pada kategori baik dikarenakan dari hasil prestasi yang diraih dalam walikota cup 2019 PB. Anugerah menjadi juara umum 2.

\section{Simpulan}

Berdasarkan hasil penelitian maka dapat diambil beberapa simpulan antara lain, organisasi yang berada di PB. Anugerah Denpasar telah berjalan cukup baik, hal itu ditunjukkan dengan pengelolaan administrasi yang baik oleh pemilik klub untuk menunjang kebutuhan atlet. Prestasi yang telah diraih di klub PB. Anugerah Denpasar cukup memuaskan diantaranya menjuarai beberapa kejuaraan di tingkat lokal Kota Denpasar dan Provinsi Bali. Hanya saja di tingkat nasional belum berprestasi. Sarana dan prasarana di PB. Anugerah Denpasar sudah milik sendiri dengan kondisi cukup memadai dan sesuai dengan standar yang ada sebagai fasilitas penunjang latihan meskipun perlu dilakukan sedikit pembenahan sarana yang ada saat ini.

\section{Daftar Pustaka}

Amirullah, H. B. (2004). Pengantar Manajemen. Yogyakarta: Graha Ilmu.

Juang, B. R. (2015). Analisis Kelebihan Dan Kelemahan Keterampilan Teknik Bermain Bulutangkis Pada Pemain Tunggal Putra Terbaik Indonesia Tahun 2014. Jurnal Kesehatan Olahraga, 3(1), 109-117.

Kusmariyatni, N. (2012). Model Brain Based Learning Dan Hasil Belajar IPA Siswa Sekolah Dasar. Jurnal Pendidikan Dan Pengajaran, 46(2).

Paramitha, S. T. (2018). Revitalisasi Pendidikan Jasmani untuk Anak Usia Dini melalui Penerapan Model Bermain Edukatif Berbasis Alam. Jurnal Pendidikan Jasmani Dan Olahraga JPJO, 3(1), 41-51.

Santoso, H.P., Rahayu, T.,\& Rahayu, S. (2017). Pembinaan Bulutangkis di Kota Magelang ( Penelitian Evaluatif Klub-klub Bulutangkis di Kota Magelang). Journal of Psysical Education and Sports, 6(2), 133-140.

Setiawan, A. (2020). Akurasi Smash Forehand Bulutangkis Dikaitkan Dengan Kekuatan Otot Lengan Dan Koordinasi Mata-Tangan. Jurnal Maenpo: Jurnal Pendidikan Jasmani Kesehatan Dan Rekreasi, 10(1).

Sholichah, A. S. (2018). Teori-Teori Pendidikan Dalam Al-Qur'an. Jurnal Edukasi Islami Jurnal Pendidikan Islam, 7(1).

Soepartono. (2000). Sarana dan Prasarana Olahraga. Jakarta: Departemen Pendidikan Nasional.

Sugiyono. (2015). Metode Penelitian dan Pendidikan (Pendekatan Kuantitatif, Kualitatif, dan $R \& D)$. Bandung: Alfabeta.

Wicaksono, G. H. (2019). Kreativitas Guru Penjas Terhadap Proses Pembelajaran Penjas Di Sekolah Menengah Pertama Negeri Sekecamatan Kebumen Kabupaten Kebumen 2018. Jurnal Pendidikan Kesehatan Rekreasi, 5(2), 95-100.

Widoyoko. (2016). Evaluasi Program Pembelajaran. Yogyakarta: Pustaka Belajar. 